\title{
2021 Handbook of Florida Water Regulation: Private Regulation ${ }^{1}$
}

\author{
Michael T. Olexa, Tatiana Borisova, and Jana Caracciolo²
}

\section{Preface}

This handbook is designed to provide an accurate, current, and authoritative summary of the principal federal and state (Florida) laws that directly or indirectly relate to agriculture. This handbook provides a basic overview of the many rights and responsibilities that farmers and farmland owners have under both federal and state laws as well as the appropriate contact information to obtain more detailed information. However, the reader should be aware that because the laws, administrative rulings, and court decisions on which this handbook is based are subject to constant revision, portions of this publication could become outdated at any time. Several details of cited laws are also left out due to space limitations. This handbook is provided as an educational text for those interested in water use and water resource issues in Florida.

This handbook is distributed with the understanding that the authors are not engaged in rendering legal or other professional advice, and the information contained herein should not be regarded as a substitute for professional advice. This handbook is not all inclusive in providing information to achieve compliance with the federal and state laws and regulations governing water protection. For these reasons, the use of these materials by any person constitutes an agreement to hold harmless the authors, the UF/IFAS Center for Agricultural and Natural Resource Law, and UF/IFAS Extension for any liability claims, damages, or expenses that may be incurred by any person as a result of reference to or reliance on the information contained in this handbook. Note: UF/IFAS is the acronym for University of Florida, Institute of Food and Agricultural Sciences.

\section{Private Regulation Overview}

Private lawsuits can be considered as a form of water resource regulations. These lawsuits are often based on two legal principles: nuisance and negligence. In addition, some federal statutes contain clauses allowing citizens to enforce laws through private lawsuits. It is important to understand how one may be held liable by other members of the public for his/her actions.

\section{What is nuisance?}

The theory of nuisance provides that one may not use one's own property in a way that causes harm to others. Nuisances are categorized as either public or private depending on whether the nuisance affects the rights of the public or only the rights of an individual. Public nuisance actions may be brought by a public official on behalf of the public at large; certain types of public nuisances may be criminal acts as well.

In nuisance actions, the court will often balance the social value of the nuisance against the harm it causes. If the harm

1. This document is FE598, one of a series of the Food and Resource Economics Department, UF/IFAS Extension. Original publication date October 1998. Revised June 2017 and April 2021. Visit the EDIS website at https://edis.ifas.ufl.edu for the currently supported version of this publication.

2. Michael T. Olexa, professor, Food and Resource Economics Department, and director, UF/IFAS Center for Agricultural and Natural Resource Law; Tatiana Borisova, associate professor, Food and Resource Economics Department; and Jana Caracciolo, student, Levin College of Law; UF/IFAS Extension, Gainesville, FL 32611.

The Institute of Food and Agricultural Sciences (IFAS) is an Equal Opportunity Institution authorized to provide research, educational information and other services

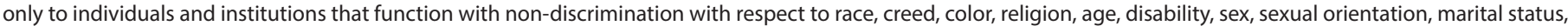

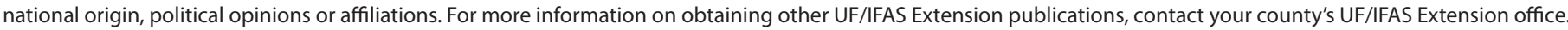
U.S. Department of Agriculture, UF/IFAS Extension Service, University of Florida, IFAS, Florida A \& M University Cooperative Extension Program, and Boards of County Commissioners Cooperating. Nick T. Place, dean for UF/IFAS Extension. 
is slight and the social value is great, the lawsuit will fail. But if the social value is small and the harm is great, the plaintiff, the party who initiated the lawsuit, may recover monetary damages and stop (enjoin) the defendant from continuing the activity.

As a defense to a nuisance claim, a defendant may assert that the plaintiff moved to the nuisance. In order for the defense to be successful, the defendant must prove that they were engaged in the offending activity before the plaintiff moved to area where the activity is occurring. For example, if a person moves next to an existing dairy operation and brings a nuisance claim because of the smell, the person will not likely win because the person knew or should have known about the smell.

Concerning nuisance lawsuits, the Florida Legislature has passed the Florida Right-to-Farm Act (FRTFA) to protect reasonable farm operations from public and private nuisance lawsuits (see FE599, Florida Right-to-Farm Act).

\section{What is negligence?}

Negligence is causing harm to someone else by failing to do what a reasonable person would have done under the same circumstances. The harm may be economic, physical, or emotional.

Anyone seeking to recover for someone else's negligence must prove four legal elements: duty, breach of duty, causation of damage, and value of damage.

1. Duty is an individual's responsibility to govern his or her own conduct so that others are not harmed.

2. Breach of duty occurs where one of the parties does not fulfill his or her duty of care (i.e., the party does not act responsibly in governing his or her own conduct so that others are harmed). When a person does not act with the degree of caution or foresight that a reasonably prudent person would have used in the same situation, that person has breached his or her duty of care.

3. Causation occurs when the defendant's failure to use due care causes harm to the plaintiff (proving this step may be difficult if the damage is only indirectly related to the defendant's act or if there are other possible causes for the harm).

4. For value of damage, the plaintiff must prove that he or she suffered actual damage from the defendant's act; if no damage resulted, even when the defendant had a duty and breached that duty, the plaintiff has no claim for negligence.

\section{What is negligence?}

Where a defendant's acts subject him or her to a private lawsuit and, at the same time, the defendant violates a statute, the court will usually regard the violation of the statute as enough evidence of wrongful conduct to find the defendant guilty of negligence in the private lawsuit. This rule applies, however, only if two conditions are met. First, the damage claimed in the lawsuit must be of the type the statute is intended to prevent. Second, the plaintiff must be a member of the class of persons the statute is intended to protect. However, compliance with all statutes does not guarantee immunity from negligence actions, as lawful behavior may still be negligent.

\section{What is strict liability?}

Strict liability is liability imposed without evidence of negligence. That is, the defendant may be found guilty on a showing that his or her action resulted in harm, without consideration of whether he or she acted reasonably (breached his or her duty of care). In other words, under strict liability, if the defendant took all reasonable precautions, yet the defendant's actions still resulted in harm to the plaintiff, then the defendant may still be liable. Strict liability is usually imposed on those who engage in abnormally dangerous or "ultra hazardous" activities (e.g., handling explosives) or other activities defined by statute (see FE584, Comprehensive Environmental Response, Compensation, and Liability Act).

\section{Sources}

Chapter 768, Florida Statutes, Section 768.81

Chapter 823, Florida Statutes, Section 823.14 (Florida's

Right to Farm Law)

\section{Acknowledgments}

The authors are indebted to the personnel of both state and federal agencies who provided their time and advice in the preparation of this handbook. We acknowledge Carol Fountain and Susan Gildersleeve at the University of Florida for their assistance in editing this handbook. We also acknowledge funding received for updating this publication from the James S. and Dorothy F. Wershow Agricultural Law Endowment. 